\title{
PELATIHAN PENULISAN KARYA ILMIAH BAGI GURU MGMP BAHASA INGGRIS SMA/MA SE-MALANG RAYA
}

\author{
Ive Emaliana $^{* 1}$, Ismarita Ida Rahmiati ${ }^{2}$, Pratnyawati Nurudi Suwarso ${ }^{3}$, Dian Inayati ${ }^{4}$ \\ 1,2,3,4 Universitas Brawijaya \\ *E-mail: ive@ub.ac.id
}

\begin{abstract}
The aim of this sustainable community service is to provide and apply knowledge related to appropriate techniques, methods and media to support the habit of writing scientific articles. The method used to achieve this goal is conduct research training and writing scientific papers that introduce scientific examples in the form of journal articles, accompany simple research planning activities, conduct progress reports, and write research reports in the form of articles, and submit journals. The results of this dedication are that participants understand the concept of developing professional work and the importance of increasing the quality and quantity of professional work development in the form of reporting on the results of classroom action research and teaching and scientific articles from research or teaching English. Of the five meetings that have been held, the training on writing scientific papers only stopped until the process of constructing abstracts because we had to accompany the teachers to do simple research before assisting in writing scientific papers.
\end{abstract}

Keywords-Socialization, Mapping, Scientific article writing

\begin{abstract}
Abstrak
Tujuan dari pengabdian kepada masyarakat tahun berkelanjutan ini adalah untuk memberikan dan menerapkan pengetahuan terkait teknik, metode, dan media yang tepat untuk mendukung pembiasaan penulisan artikel ilmiah. Metode yang digunakan untuk mencapai tujuan ini adalah dengan menyelenggarakan pelatihan penelitian dan penulisan karya ilmiah yang memperkenalkan pada contoh-contoh karya ilmiah berupa artikel jurnal, mendampingi kegiatan perencanaan penelitian sederhana, melakukan progress report, dan menulis laporan penelitian dalam bentuk artikel, serta melakukan submit jurnal. Hasil dari pengabdian ini adalah peserta memahami konsep pengembangan karya profesi dan pentingnya peningkatan kualitas maupun kuantitas karya pengembangan karya profesi berbentuk pelaporan hasil penelitian tindakan kelas dan pengajaran serta artikel ilmiah dari penelitian atau pengajaran bahasa Inggris. Dari lima pertemuan yang telah diselenggarakan, pelatihan penulisan karya ilmiah ini hanya berhenti hingga proses pembuatan abstrak dikarenakan kami harus mendampingi para guru untuk melakukan penelitian sederhana sebelum mendampingi dalam menulis karya ilmiah.
\end{abstract}

Kata kunci-Sosialisasi, Pemetaan, Penulisan artikel Ilmiah

\section{PENDAHULUAN}

Pada Undang-Undang No. 14 Tahun 2005 pasal 10 tentang Guru dan Dosen dituliskan bahwa guru profesional wajib mempunyai empat kompetensi, yaitu kompetensi pedagogik, kompetensi kepribadian, kompetensi sosial, dan kompetensi profesional. Kompetensi Pedagogik merupakan kemampuan pemahaman terhadap peserta didik, perancangan dan pelaksanaan pembelajaran, evaluasi hasil belajar, dan pengembangan peserta didik untuk mengaktualisasikan berbagai potensi yang dimilikinya. Kompetensi kepribadian merupakan kemampuan personal yang mencerminkan kepribadian yang mantap, stabil, dewasa, arif dan berwibawa, menjadi teladan bagi peserta didik, dan berakhlak mulia. Kompetensi profesional merupakan penguasaan materi pembelajaran secara luas dan mendalam, yang mencakup penguasaan materi kurikulum mata pelajaran di sekolah dan substansi keilmuan yang menaungi materinya, serta penguasaan terhadap struktur dan metodologi keilmuannya. Kompetensi Sosial merupakan kemampuan guru untuk 
berkomunikasi dan bergaul secara efektif dengan peserta didik, tenaga kependidikan, orang tua/wali peserta didik, dan masyarakat sekitar[1].

Salah satu cara untuk meningkatkan kompetensi keempat kompetensi tersebut adalah dengan menulis. Melalui menulis, seseorang tentu akan berusaha mencari, membaca, dan menelaah referensi-refrensi yang akan terkait dengan bahan yang akan ditulis[2]. Dengan demikian, kompetensi pedagogic guru akan meningkat. Kemudian melalui menulis, guru dapat menjadi inspirasi bagi peserta didik. Mestinya guru tidak hanya meminta peserta didiknya agar berkarya melalui tulisan namun guru juga mampu menampilkan karya tulisnya. Sehingga, guru dapat menjadi teladan yang baik bagi peserta didik dalam berkarya. Dengan demikian, kompetensi kepribadian guru akan meningkat. Dengan menulis karya ilmiah guru dapat meningkatkan kesejahteraan sosial. Sesuai yang tertulis pada Peraturan Bersama Mendiknas Nomor 03/V/Pb/2010 dan Kepala BKN Nomor 14 Tahun 2010 Pasal 17 ayat 2 menyebutkan bahwa untuk kenaikan jabatan wajib melakukan kegiatan pengembangan keprofesian berkelanjutan yang meliputi sub unsur pengembangan diri, publikasi ilmiah, dan/atau karya inovatif. Melalui menulis pula, guru dapat membagikan pengalaman-pengalaman pengajaran seperti metode, teknik, media pembelajaran yang efektif diterapkan di kelas ke khalayak umum. Selain itu, guru juga dapat mengutarakan hambatan-hambatan mengajar yang telah ditemukan di kelas[3]. Hal tersebut dapat meningkatkan kompetensi profesional guru.

Peningkatan kompetensi guru akan berampak positif bagi kemajuan peserta didik. Hal ini, sejalan dengan hasil penelitian yang dilakukan oleh[4] bahwa kompetensi guru (pedagogical content knowledge, self-efficacy, and teaching enthusiasm) secara positif berhubungan erat dengan hasil prestasi peserta didik. Itu artinya bahwa profesionalitas guru akan meningkat salah satunya melalui kegiatan menulis. Dengan demikian, diperlukan pengembangan kompetensi guru yang dilaksanakan sesuai dengan kebutuhan, bertahap, dan berkelanjutan untuk meningkatkan kompetensi-kompetesi yang wajib dimiliki oleh guru[5]. Berdasarkan Permennegpan dan reformasi Birokrasi no. 16 Tahun 2009, pengembangan kompetensi guru tersebut diatur dalam pengembangan keprofesian berkelanjutan yang merupakan salah satu komponen pada unsur utama yang kegiatannya diberikan angka kredit. Disamping itu, unsur utama yang lain, sebagaimana dijelaskan pada bab V pasal 11, adalah pendidikan dan pembelajaran/ bimbingan. Unsur kegiatan pengembangan keprofesian berkelanjutan terdiri atas tiga macam, yaitu (1) pengembangan diri, (2) publikasi ilmiah, dan (3) karya inovatif. Pengembangan diri dapat dilakukan dengan mengikuti diklat fungsional dan melaksanakan kegiatan kolektif guru. Publikasi ilmiah dapat dilakukan dengan membuat publikasi ilmiah atas hasil penelitian berupa artikel atau buku[6]. Sedangkan karya inovatif merupakan kegiatan yang meliputi menemukan teknologi tetap guna, menemukan atau menciptakan karya seni, membuat atau memodifikasi alat pelajaran, dan mengikuti pengembangan penyusunan standar, pedoman, soal dan sejenisnya[7].

Dalam upaya memenuhi tuntutan kualifikasi dan diikuti dengan hak yang seharusnya diperoleh guru, dalam kenyataannya, kenaikan pangkat terkendala oleh adanya persyaratan penulisan karya ilmiah guru. Secara konseptual, artikel ilmiah merupakan bagian yang esensial bagi pengembangan profesi guru yaitu dengan melakukan tindakan reflektif pada kegiatan mengajarnya[8]. Mengingat kondisi yang terjadi saat ini, diperlukan berbagai upaya untuk membantu guru keluar dari masalah kesulitan memperoleh kredit dari artikel ilmiah[9]. Untuk hal itu diperlukan sosialisasi pelatihan dan pendampingan penulisan artikel ilmiah dari para ahli, sekaligus pemetaan terhadap kondisi terkini terhadap kegiatan pelatihan atau pendampingan artikel ilmiah yang didapatkan guru.

Justifikasi tim pengusul bersama mitra, yaitu guru MGMP Bahasa Inggris SMA/SMK seMalang sebagai prioritas permasalahan yang harus ditangani, didasarkan pada hasil wawancara informal dengan ketua MGMP Bahasa Inggris SMA/SMK se-Malang dan hasil sosialisasi dan pemetaan masalah yang dilakukan pada pengabdian masyarakat DPP/SPP pada tahun 2018 dengan hasil bahwa motivasi menulis karya ilmiah guru MGMP Bahasa Inggris SMA/MA di Malang dipetakan dengan hasil 95\% guru ingin mengembangkan skill dan kepekaan dalam menulis karya ilmiah, 90\% para guru ingin meningkatkan belajar dan meningkatkan kemampuan kepenulisan dalam pelatihan dan pendampingan penulisan karya ilmiah. Peserta juga menyatakan bahwa dalam pelatihan dan pendampingan penulisan karya ilmiah (90\%), para guru ingin mendapatkan informasi cara melakukan penelitian (100\%), ingin menghasilkan sebuah karya ilmiah dan ingin 
mendapatkan pendampingan hingga selesai (95\%). Dari 49 peserta, hanya 5\% sudah pernah menulis karya ilmiah sebelumnya. Disamping itu, informasi tentang kemampuan guru dalam menulis karya ilmiah, terpetakan sebagai berikut. Hanya 25\% dari para guru mengetahui cara penulisan karya ilmiah yang benar dan tepat, namun 95\% para guru memerlukan pelatihan dan pendampingan untuk mengetahui cara menulis karya ilmiah yang benar dan tepat, meskipun 55\% para guru sudah pernah ikut seminar atau workshop cara penulisan karya ilmiah yang benar dan tepat, namun lupa atau tidak dipraktekkan untuk menulis karya ilmiah. Sehubungan dengan hal ini, kendala dalam menulis karya ilmiah para guru yang teridentifikasikan adalah kurangnya motivasi dan tidak percaya diri dalam menulis karya ilmiah (80\%), kurang fokus untuk menulis karya ilmiah (85\%), kesulitan dengan kebahasaan yang formal dan akademik dalam menulis karya ilmiah (90\%), terbatasnya wadah pelatihan penulisan karya ilmiah (90\%), dan memerlukan pembiasaan salah satunya dengan pendampingan menulis karya ilmiah (100\%). Berdasarkan hasil informasi yang didapatkan, seminar atau pun workshop mengenai penulisan artikel ilmiah ini pernah dilakukan, namun belum sepenuhnya dilakukan penulisan karena berbagai kendala seperti kendala internal maupun eksternal pada guru.

Menyadari hal tersebut, diperoleh suatu konklusi bahwa sosialisasi pentingnya artikel ilmiah perlu diadakan sekaligus pemetaan permasalahan internal dan eksternal tentang penulisan karya ilmiah sangat diperlukan untuk dapat melakukan penelitian yang menunjang penulisan karya ilmiah sesuai dengan standar yang ditetapkan. Permasalahan spesifik yang berhasil diidentifikasi bersama tim pengusul adalah sebagai berikut.

1. Para guru MGMP Bahasa Inggris SMA/MA di Malang belum memiliki motivasi dalam mewujudkan ragam kegiatan pengembangan profesi, khususnya penulisan artikel ilmiah guru

2. Belum tersedia pemetaan untuk potensi dan tantangan dari guru MGMP Bahasa Inggris SMA/MA di Malang mengenai penulisan artikel ilmiah sebagai pengembangan profesi guru

3. Para guru MGMP Bahasa Inggris SMA/MA di Malang perlu memperoleh sosialisasi ragam jenis pengembangan profesi guru yang merujuk pada penulisan artikel ilmiah dan pemetaan potensi dan tantangan terhadap pelaksanaan pembinaan dan pendampingan penulisan karya ilmiah guru dari pihak yang kompeten

\section{METODE}

Metode yang digunakan dalam pengabdian masyarakat ini adalah metode ceramah dan diskusi. Fokus utama kegiatan pengabdian ini adalah para guru MGMP Bahasa Inggris SMA/MA di Malang. Jumlah khalayak sasaran adalah sekitar 50 orang yang diharapkan pada akhir kegiatan bisa melahirkan ide artikel yang siap untuk dipublikasikan. Kegiatan pelatihan penulisan artikel ini memiliki keterkaitan dengan upaya untuk meningkatkan tradisi intelektual karena para guru adalah sumber inspirasi dan bagian penting dari dunia pendidikan. Berbagai latar belakang berbeda dari para peserta akan membuat beragam gaya dan ide penulisan artikel mereka. Hal ini akan memberi manfaat bagi dunia pendidikan. Kerangka pemecahan masalah dalam pengabdian ini dirumuskan dalam beberapa metode pelaksaaan sebagai berikut.

1. Tahap awal akan dimulai dengan melakukan observasi tentang potensi para guru Bahasa Inggris SMA/SMA se-Malang. Observasi ini dilakukan dengan menghadiri acara-acara yang dilakukan komunitas ini untuk mendapatkan berbagai data yang diperlukan.

2. Tahap kedua, tim pengabdian akan mempersiapkan berbagai materi yang terkait dengan pengenalan dunia penulisan artikel secara umum. Materi-materi ini disesuasikan dengan pengalaman dan heterogenitas para guru Bahasa Inggris SMA/MA se-Malang.

3. Tahap berikutnya yaitu pelaksanaan. Tahap ini di bagi dalam tiga tahap. Pertama, peserta akan dikenalkan pada contoh-contoh karya ilmiah berupa artikel jurnal, kedua peserta didampingi untuk melakukan perencanaan penelitian sederhana, ketiga peserta didampingi untuk melakukan progress report, keempat, peserta didampingi untuk menulis laporan penelitian dalam bentuk artikel, dan kelima, peserta didampingi untuk melakukan submit jurnal. 
Materi yang digunakan dalam pengabdian masyarakat ini berupa:

1. Modul yang berisikian tentang pentingnya penulisan karya ilmiah, jenis metodologi penelitian yang dapat diaplikasikan untuk penulisan karya ilmiah, topik-topik terkini yang menggunakan metode penelitian tindakan kelas, dan contoh-contoh artikel jurnal- modul terlampir.

2. Handout berupa ringkasan materi serta langkah-langkah penulisan artikel.

Pengabdian dalam bidang penulisan artikel ini menggunakan metode sebagai berikut:

a. Peserta akan diberi kesempatan untuk melakukan eksplorasi ide. Dalam proses eksplorasi ini metode 'brainstroming' dan 'free writing' akan digunakan. Hal ini penting dilakukan karena kelahiran ide bisa muncul baik ketika pelatihan berlangsung maupun ketika peserta berada di luar ruang pelatihan.

b. Peserta diajak untuk memahami berbagai unsur artikel. Dengan mengetahui elemenelemen dasar ini, peserta diharapkan bisa menulis artikel dengan baik. Beberapa contoh artikel, terutama yang sudah dipublikasikan, akan diberikan untuk menjelaskan unsurunsur penting dalam artikel, seperti paragraf pembuka, hingga kesimpulan.

c. Praktik menulis secara bertahap akan dilakukan. Pada tahap awal, peserta dipersilakan untuk menuliskan ide dan mengembangkannya. Kemudian pada tahap berikutnya. proses revisi dan editing, baik dari aspek teknik penulisan hingga isi, akan dilakukan untuk memperbaiki dan mempertajam artikel.

d. Pada tahap berikutnya, diharapkan artikel yang telah dilahirkan bisa dibukukan.

\section{HASIL DAN PEMBAHASAN}

Program ini dilaksanakan sebanyak 5 kali dan hasilnya adalah sebagai berikut. Pada pertama, dilakukan penyampaian materi tentang pentingnya publikasi karya ilmiah bagi para guru dan informal focus-group discussion kepada para guru peserta MGMP Bahasa Inggris mengenai kesiapannya untuk penulisan artikel untuk diterbitkan di jurnal. Pada pertemuan ini didapatkan informasi bahwa para guru masih belum ada yang melaksanakan penelitian yang mana datanya digunakan untuk menulis artikel untuk jurnal. Pada pertemuan pertama ini, modul pengabdian masyarakat dibagikan untuk dapat digunakan pada pertemuan selanjutnya. Pada pertemuan ini, akhirnya terjadi kesepakatan materi dan pendampingan yang dapat dilakukan untuk pengbdian masyarakat ini.

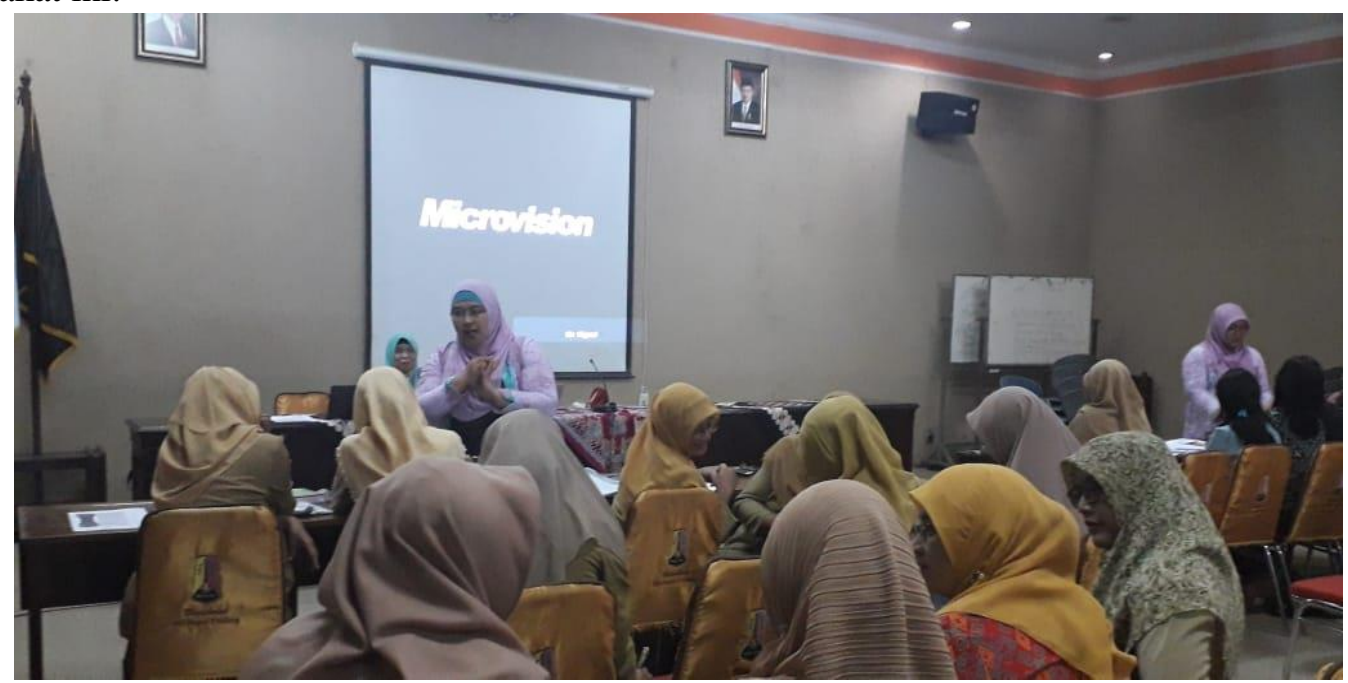

Gambar 1 Diskusi dan Pembimbingan oleh Pemateri dalam Penulisan Artikel

Pertemuan kedua salah satu agenda dalam program tersebut adalah penyampaian materi oleh pemateri yang sesuai dengan modul yaitu mengenai jenis metodologi penelitian yang dapat diaplikasikan untuk penulisan karya ilmiah. Tanya jawab berlangsung secara dinamis. Pada pertemuan kedua ini, selain modul, digunakan pulan handout berisikan masalah mengajar yang timbul dan deskripsi singkat tentang permasalahan pembelajaran (yang terbagi atas masalah pembelajaran dan data pendukung, yang berupa hasil tes, wawancara dengan peserta didik, 
pengamatan guru, maupun data pendukung lain). Guru melakukan pengelompokan secara mandiri dalam menjawab pertanyaan yang ada. Dalam mengisi handout, guru didampingi oleh setiap dosen dari FIB yang melaksanakan pengabdian masyarakat.

Pertemuan ketiga dengan penyampaian materi oleh pemateri yang sesuai dengan modul yaitu mengenai topik-topik terkini yang menggunakan metode penelitian tindakan kelas. Tanya jawab berlangsung secara dinamis, terutama dalam melaporkan data dukung untuk permasalahan pembelajaran bahasa Inggris. Para Guru juga masih ada yang mulai mengisi kembali handout tersebut.

Pertemuan keempat dengan agenda penyampaian materi oleh pemateri mengenai contoh sebuah artikel dari jurnal yang dapat digunakan sebagai contoh dalam menulis hasil penelitian. Disamping itu, para guru masih mendiskusikan beberapa hasil mini riset yang dilakukan pada kelas belio secara individual maupun secara berkelompok. Acara ini kemudian dilanjutkan dengan penulisan abstrak penelitian. Beberapa guru menulis di laptop, tetapi banyak juga yang masih menulis di kertas. Diskusi antara para guru dan pemateri dari tim pengabdian masyarakat dari FIB berlangsung secara dinamis.

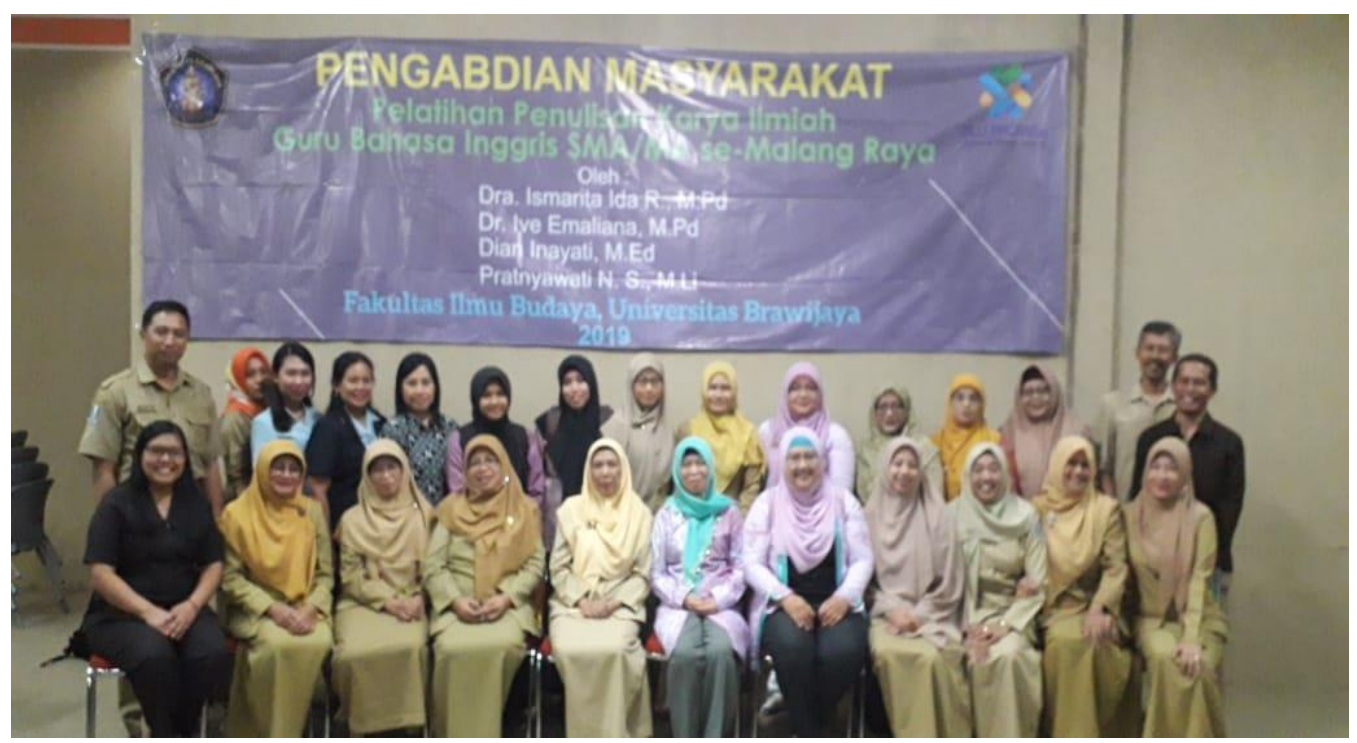

Gambar 2 Peserta dan Pemateri pada Akhir Sesi Kegiatan

Pertemuan kelima ini, diisi dengan pemantapan penulisan abstrak oleh peserta yang didampingi oleh pemateri dan dosen pendamping. Para guru masih menanyakan tentang abstract yang mereka buat dalam bahasa Inggris. Beberapa guru melakukan presentasi terhadap isi asbtract tersebut. Disamnping itu, karena ini pertemuan terakhir, maka, evaluasi kegiatan dilakukan melalui survei. Hasil dari survei tersebut adalah sebagai berikut.

- Gaya penulisan, yang meliputi format tulisan, gaya, sistematika tulisan, cara pengutipan, penyajian intrumen pendukung seperti bagan, catatan kaki dan lain sebagainya.

\begin{tabular}{clcc}
\hline No & \multicolumn{1}{c}{ Pernyataan } & Ya & Ragu \\
\hline 1. & Materi yang diberikan terdapat kebaharuan & $85 \%$ & $15 \%$ \\
& (informasinya ada yang baru saja anda dapatkan). & $100 \%$ & $0 \%$ \\
\hline 2. & Materi cocok dengan judul acara. & $95 \%$ & $5 \%$ \\
\hline 3. & Materi sangat bermanfaat. & $95 \%$ & $5 \%$ \\
\hline 4. & Materi yang disampaikan secara efektif dan efisien. & $90 \%$ & $10 \%$ \\
\hline 5. & Materi cukup menarik. & & \\
\hline
\end{tabular}

- Subtansi yang meliputi cakupan keilmuan, orisinalitas, analisa dan sintesis serta derajat kemutakhiran pustaka.

\begin{tabular}{cccc}
\hline No & Pernyataan & Ya & Ragu \\
\hline 1. & Pemateri menjelaskan informasi dengan jelas. & $100 \%$ & $0 \%$ \\
\hline
\end{tabular}


2. Pemateri menjelaskan materi secara efektif dan efisien. $95 \%$ $5 \%$

3. Pertanyaan dari audiens direspon secara efektif. $95 \%$ $5 \%$

Selain hasil positif dari kuisioner pelaksanaan tersebut, pelatihan dan pendampingan penulisan artikel untuk diterbitkan ke jurnal nasional ini hanya sampai pada tahap pembuatan abstrak. Karena keterbatasan waktu, kelanjutan kegiatan ini akan diselenggarakan selanjutnya di tahun depan, sebagaimana memang keberlanjutan dari program pengabdian masyarakat ini. Keberlanjutan pelatihan penulisan karya ilmiah dapat meningkatkan kesadaran maupun kebiasaan[10] sehingga dapat membantu peningkatan kompetensi para guru[11].

\section{KESIMPULAN}

Pelaksanaan pengabdian masyarakat pada guru bahasa Inggris se-Malang Raya berjalan dengan lancar. Hal ini ditandai dengan $90 \%$ peserta merasakan kebermanfaatan mengikuti pelatihan penulisan karya ilmiah ini. Hasil dari pengabdian ini adalah peserta memahami konsep pengembangan karya profesi dan pentingnya peningkatan kualitas maupun kuantitas pengembangan karya profesi berbentuk penelitian sederhana dan abstrak artikel ilmiah dari hasil penelitian. Pelaksanaan pengabdian untuk guru-guru bahasa Inggris dapat disimpulkan berhasil sampai tahap pelatihan penelitian sederhana dan pelatihan penulisan abstrak karya ilmiah. Pelatihan berkelanjutan ini diharapkan dapat menghasilkan karya tulis ilmiah terpublikasi agar kompetensi pedagogik, kompetensi kepribadian, kompetensi sosial, dan kompetensi professional guru dapat meningkat dan kegiatan menulis artikel menjadi budaya bagi guru bahasa Inggris seMalang Raya.

\section{SARAN}

Dari sosialisasi dan pelatihan yang diadakan, saran yang diberikan kepada guru adalah agar guru dapat mengembangkan kreativitasnya dalam bentuk karya ilmiah yang dapat dibagikan ke khalayak umum baik keefektifan mengajar ataupun hambatan mengajar dikelas. Kemudian saran dari guru adalah guru meminta agar ada pembimbingan berkala mengenai penulisan karya ilmiah agar hasil karya ilmiah lebih terarah dan tetap termotivasi untuk menggali isu-isu yang sedang berkembang untuk diteliti.

\section{UCAPAN TERIMA KASIH}

Penulis mengucapkan terima kasih kepada Fakultas Ilmu Budaya Universitas Brawijaya yang telah memberikan dukungan finansial terhadap pengabdian masyarakat ini berdasarkan surat perjanjian No. 1212.1/UN10.F12/PM/2019

\section{DAFTAR PUSTAKA}

[1] “Undang-undang Guru dan Dose 2005." .

[2] Nanik Setyawati, Larasati Larasati, Zainal Arifin, Arisul Ulumuddin, "IbM PENINGKATAN KOMPETENSI MENULIS ARTIKEL MEDIA MASSA BERMUATAN PENDIDIKAN KARAKTER UNTUK MENCIPTAKAN GURU KREATIF DAN PRODUKTIF DI KOTA SEMARANG," E-Dimas Educ.-Pengabdi. Kpd. Masy., vol. 4, no. 1, pp. 1-12, 2014.

[3] Ibnu Sodiq, Andy Suryadi, Tsabit Azinar Ahmad, "Program Guru Menulis: Upaya Peningkatan Kompetensi Profesional Guru Sejarah dalam Penulisan Karya Ilmiah di Kabupaten Semarang," Rekayasa, vol. 12, no. 1, pp. 42-47, 2014.

[4] B. Fauth, J. Decristan, A.T. Büttner, I. Hardy, E. Klieme, and M. Kunter, "The effects of teacher competence on student outcomes in elementary science education: The mediating role of teaching quality.," Teach. Teach. Educ., vol. 86.

[5] Hernowo, Menjadi Guru yang Mampu dan Mau Membuat Buku. Bandung: MLC, 2005.

[6] Imam Gunawan, Teguh Triwiyanto, and Desi Eri Kusumaningrum, "PENDAMPINGAN PENULISAN ARTIKEL ILMIAH BAGI PARA GURU SEKOLAH MENENGAH PERTAMA," Abdimas Pedagogi, vol. 1, no. 2, pp. 128-135, 2018. 
[7] Wawan Krismanto, "Meningkatkan Kemampuan Publikasi Ilmiah Kalangan Guru Sekolah Dasar," J. Dedik., vol. 20, no. 1, pp. 112-118, 2018.

[8] Lilies Noorjannah, "PENGEMBANGAN PROFESIONALISME GURU MELALUI PENULISANKARYATULIS ILMIAH BAGI GURU PROFESIONAL DI SMA NEGERI 1KAUMAN KABUPATEN TULUNGAGUNG," J. HUMANITY, vol. 10, no. 1, pp. 98-114, 2014.

[9] Putut Marwoto, Achmad Sopyan, Suharto Linuwih, Bambang Subali, and Ellianawati, "PENINGKATAN KEMAMPUAN MENULIS ARTIKEL ILMIAH SAINS GURU SEKOLAH DASAR MELALUI KEGIATAN PENGABDIAN MASYARAKAT," ABDIMAS, vol. 17, no. 2, pp. 111-116, 2013.

[10]Fahd Djibran, Writing Is Amazing: A Guidebook of Writing. Yogyakarta: Junktapose, 2007.

[11]H.B. N. Tanjung and H. Ardial, Pedoman penulisan karya ilmiah dan mempersiapkan diri menjadi penulis artikel ilmiah, 2010th ed. Jakarta: Prenada Media Group. 